\title{
DEDICATION
}

\section{Wolfgang Becker (1952-2002)}

It is hard to believe that, by the time this journal started, it is 7 years since Wolfgang Becker MD, PhD, passed away. He was only 49 years old. However, in such a relatively short life span, he had accomplished so much both in his personal and professional life that speaks for him everyday and keeps him alive, in a way, even after his death.

He was born in 1952, in Uffenheim, Mittelfranken, Germany. In 1979, he obtained his MD degree from the University of Würzburg. He then served in German army and began his Nuclear Medicine career in 1981 at the University of Würzburg. While working there, he developed interest in then a relatively new field of imaging infection with In-111-oxine and used his clinical findings for his PhD degree which he obtained in 1987. In 1988, he moved to the University of Nürnberg-Erlangen as a Professor of Nuclear Medicine and then in 1995 to the University of Göttingen as the Chair of the Department of Nuclear Medicine. He worked at Göttingen until his demise.

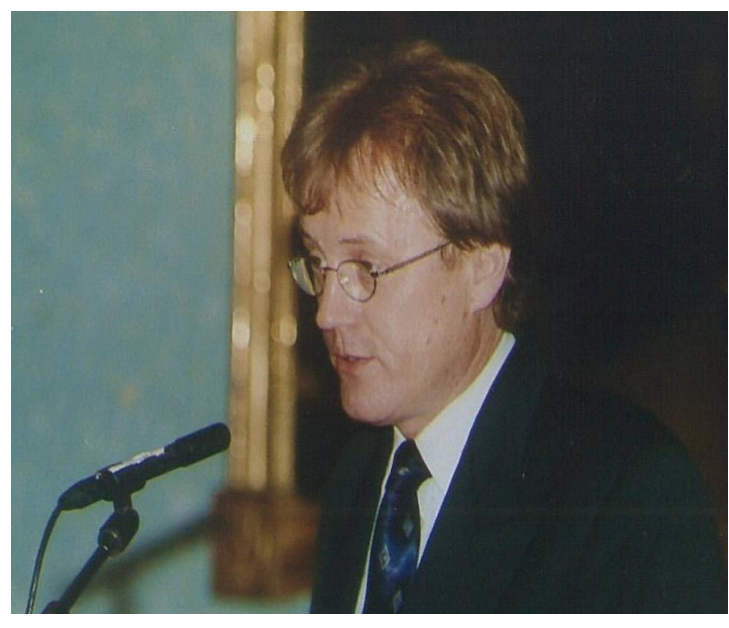

His interest in In-111 labeled white blood cells and their continued innovative applications in patients, mark one of his major contributions to clinical science in Nuclear Medicine. He gave several presentations on this topic in national and international gatherings, wrote more than 140 original papers and numerous review articles. He was certainly among the few who have helped to establish the art of infection imaging using radiolabeled white blood cells. He was one of the 80 participants at the North Atlantic Treaty Organization's Advanced Study Institute that I, as the inventor of In-111-oxine labeled white blood cells, with my colleague and friend Dr. John McAfee, had directed in 1983 in Maratea, Italy. That was my first encounter with Wolfgang, which led to a deep friendship bonded by common scientific interest, common ideology, and warm respect for each other.

His qualities in life, creativity, and hard work to accomplish his goals, brought him many more friends and admirers. For the 20002002 term, he was elected as the President of European Association of Nuclear Medicine (EANM), the challenge he sought to serve nuclear medicine community and the field, beyond his own university and country. Despite his illness during the same time, he served the association with vision and vigor. He passed away before his term was over but during that time, he had proved to be an excellent leader. He deeply cared for issues that confronted the field, fought battles, yet made no enemies. He was persuasive and decisive. He worked with his counterparts in other Nuclear Medicine organizations and worked with them for common goals. He worked long hours professionally but did not neglect his family which he loved dearly.

As a man he was calm, pleasant, and a good listener. As a friend, he was supportive and warm. As a scientist, he was creative and conclusive, and as a leader, he was persuasive and decisive. It were these qualities that brought him the friends and the fame, all in less than 50 years of his life span.

I am glad that the Editor-in-Chief Prof. Helmut Sinzinger has chosen to dedicate this journal to Wolfgang. Although these words are only a few, these will revive the memory of many of those who had worked with Prof. Wolfgang Becker, known him as a friend, witnessed him as a leader, and heard him as a scientist. I am grateful to Dr. Sinzinger for giving me the opportunity to pay my respect, once again, to Wolfgang Becker, MD, PhD.

Mathew L. Thakur Laboratories of Radiopharmaceutical Research and Molecular Imaging Radiology \& Radiation Oncology Thomas Jefferson University Philadelphia PA 19107 USA

Past President of SNM E-mail: mathew.thakur@jefferson.edu

(C) Mathew L. Thakur; Licensee Bentham Open.

This is an open access article licensed under the terms of the Creative Commons Attribution Non-Commercial License (http: //creativecommons.org/licenses/by-nc/ 3.0/) which permits unrestricted, non-commercial use, distribution and reproduction in any medium, provided the work is properly cited. 